Sains Malaysiana 49(5)(2020): 1015-1020

http://dx.doi.org/10.17576/jsm-2020-4905-06

\title{
Reliability of Pterygium Redness Grading Software (PRGS) in Describing Different Types of Primary Pterygia Based on Appearance
}

(Kebolehpercayaan Perisian Penggredan Kemerahan Pterigium (PRGS) dalam Mengelaskan Pelbagai Jenis Pterigium Berdasarkan Perawakan)

\author{
Mohd Radzi Hilmi, Mohd Zulfaezal Che Azemin, Khairidzan Mohd Kamal*, AzRin Esmady ARIfFin, \\ MUHAMMAD AFZAM SHAH ABDUl RAHIM \& MOHD IZZUDDIN MOHD TAMRIN
}

\begin{abstract}
The aim of this study was to evaluate the reliability of Pterygium Redness Grading Software (PRGS) in describing different types of primary pterygia. Ninety-three participants with primary pterygia who visited an ophthalmology clinic were recruited in this study. PRGS is a semi-automated computer program used to measure fibrovascular pterygium redness by analysing digital images of the pterygium and grading it on a continuous scale of 1 (minimum redness) to 3 (maximum redness). An ocular surface expert graded all 93 images in random order. The reliability of PRGS was determined by comparing pterygium redness measured using the software and by the expert. The mean and standard deviation of redness of the pterygium fibrovascular images measured using PRGS and by the expert were $1.81 \pm 0.58$ and $1.73 \pm 0.61$, respectively $(P=0.396)$. A comparative analysis based on pterygium type showed an increase in redness according to pterygium type (Type I: $1.43 \pm 0.32$; Type II: $1.67 \pm 0.55$; and Type III: 2.31 $\pm 0.46)$, without significant differences compared to redness measured by the expert (Type I: 1.38 \pm 0.34 ; Type II: $1.78 \pm 0.62$; and Type III: $2.02 \pm 0.66$ ) (all P > 0.05). PRGS could describe and classify pterygia according to their redness, and PRGS-based classification was in agreement with the established classification of pterygia. Therefore, PRGS can be used in addition to the existing pterygium grading system.
\end{abstract}

Keywords: Automate; morphology; pterygium; redness; translucence

ABSTRAK

Matlamat kajian ini adalah untuk menilai kebolehpercayaan Perisian Penggredan Kemerahan Pterygium (PRGS) dalam mengelaskan jenis-jenis pterigium primer. Kajian ini berjaya merekrut 93 pesakit daripada klinik oftalmologi yang menghidap pterigium primer. PRGS merupakan program komputer semi-automatik yang berfungsi untuk mengukur darjah kemerahan pterigium fibrovaskular yang diperoleh daripada imej digital pterigium, dalam bentuk pengredan berterusan (1 untuk kemerahan minimum dan 3 untuk kemerahan maksimum). Kesemua 93 imej pterigium telah digredkan secara rambang oleh pakar permukaan okul. Kebolehpercayaan PRGS telahpun ditentukan dengan membandingkannya dengan kemerahan yang dicerap oleh pakar. Nilai min dan sisihan piawai untuk kemerahan pterigium fibrovaskular adalah $1.81 \pm 0.58$ (PRGS) dan $1.73 \pm 0.61$ (pakar), $(P=0.396)$. Analisis berasaskan jenis pterigium menunjukkan terdapat peningkatan kemerahan pterigium fibrovaskular apabila diukur menggunakan PRGS (Jenis I: $1.43 \pm 0.32$; Jenis II: $1.67 \pm 0.55$; Jenis III: $2.31 \pm 0.46$ ) berbanding pakar (Jenis I: $1.38 \pm 0.34$; Jenis II: $1.78 \pm 0.62$; Jenis III: $2.02 \pm 0.66)$, tetapi perbezaan ini tidak signifikan untuk semua jenis pterigium $(P$ $>0.05)$. Skala pengredan PRGS dapat mengelaskan pterigium berdasarkan kemerahan dan ia selaras dengan pengelasan pterigium sedia ada. Skala kemerahan ini boleh digunakan sebagai tambahan kepada pengredan pterigium yang sedia ada.

Kata kunci: Automatik; kemerahan; morfologi; pterigium; translusen

\section{INTRODUCTION}

Pesticides Pterygium is an abnormal fibrovascular growth which originates from the conjunctiva and encroaches the central cornea (Manzar \& Mahar 2013; Mohd Radzi et al. 2017), and it is caused by chronic exposure to ultraviolet rays (Bradley et al. 2010; Chui et al. 2011; Hilmi et al. 2018; Modenese \& Gobba 2017; Oellers et al. 2013). The severity of pterygium has been clinically described on the basis of its length (extension) (Gumus et al. 2011; Kheirkhah et al. 2012a; Kheirkhah et al. 2012b; Mohammad-Salih \& Sharif 2008) and size (Altan-Yaycioglu et al. 2013; Farhood \& Kareem 2012; Vives et al. 2013). However, studies on the morphological features of pterygium, such as redness, which could also act as an indicator of disease severity are lacking. Pterygium Redness Grading Software (PRGS) was 
developed to address this issue by introducing redness as an indicator to determine the effects of different types of pterygia on corneal curvature (Azemin et al. 2014; Che Azemin et al. 2015, 2014; Mohd Radzi et al. 2017).

Preliminary studies (Azemin et al. 2014; Che Azemin et al. 2015, 2014) attempted to quantify and describe pterygium redness using extensive image analysis combining colour-space conversion, colour layers, textural descriptors, and feature selection technique. The introduction of the semi-automated PRGS has allowed the grading of pterygium redness on a continuous scale of 1 (minimum redness) to 3 (maximum redness) (Mohd Radzi et al. 2017). Recent histological evidence (AltanYaycioglu et al. 2013; Park et al. 2015) suggests that pterygium is composed of fibrovascular tissue; hence, redness is an important element in describing pterygium. Redness indirectly signifies tissue growth, whereby more redness reflects more aggressive pterygium growth and faster progression. Thus, with the development of PRGS, this clinically important pterygium morphology can be clinically applied for evaluating and managing patients with pterygium. To the best of our knowledge, no previous study has described pterygium redness.

In 1997, Tan et al. proposed a clinical grading based on pterygium translucency which corresponds to an increase in the fleshiness of the fibrovascular components of pterygium. This clinical grading is based on the morphological appearance of pterygium. Other authors had proposed different subjectively measured clinical grading systems based on the extent of pterygium progression from the limbus to the central cornea via slitlamp biomicroscopy examination (Farhood \& Kareem 2012; Manzar \& Mahar 2013; Mohammad-Salih \& Sharif 2008). Although both these grading systems have clinical applicability, the inter-grader variability is high, especially in the latter approach. Hence, the current study aimed to determine the repeatability and reliability of the semi-automated PRGS in describing different types of pterygia based on pterygium redness.

\section{MATERIALS AND METHODS}

This study recruited 93 eyes of 93 participants with primary pterygia who visited an ophthalmology clinic. We used digitised pterygium images and other data obtained during the baseline visit. Image acquisition, analyses, and clinical grading were performed as previously described (Che Azemin et al. 2015, 2014; Hilmi et al. 2019; Mohd Radzi et al. 2017). All participants were selected on the basis of the following specific criteria: participants with an established diagnosis of primary pterygium; participants of both sexes with ages ranging from 20 to 70 years; and those without any history of ocular trauma, ocular surgery, contact lens wear, and any ocular anterior segment disease other than pterygium which may affect vision (Che Azemin et al. 2015, 2014; Hilmi et al. 2019; Mohd Radzi et al. 2017). Assessment of primary pterygium and its classification were carried out by a consultant ophthalmologist (KMK). The study was conducted according to the recommendation of the tenets of the Declaration of Helsinki and was approved by the International Islamic University Malaysia (IIUM) ethical research committee (IIUM/310/G13/4/4-125). Written informed consent was obtained from all participants before they underwent any procedures.

For reliability testing, the consultant ophthalmologist (KMK) graded each of the 93 images on the basis of Tan's classification (Tan et al. 1997) into Type I (atrophic), Type II (intermediate), and Type III (fleshy), and subjectively graded pterygium redness on the basis of previous scales (Mohd Radzi et al. 2017) by using PRGS. The set of images was randomised using Research Randomizer software (Urbaniak \& Plous 2013). Thereafter, PRGS was employed, and the amount of redness was recorded for each image. Comparative analyses were conducted by evaluating the association between the redness measured using PRGS and each type of pterygium, as graded by the consultant ophthalmologist.

Statistical analyses were carried out using IBM SPSS Statistics for Windows/Macintosh, Version 24.0 (IBM Corp., Armonk, NY, USA). The reliability of PRGS was assessed using intraclass correlation coefficients (ICCs). The alpha significance level was set at $\mathrm{P}<0.05$. The difference between PRGS and expert grading was compared using a paired t-test for each pterygium group. All data were described according to pterygium types (Type I: atrophy; Type II: intermediate; and Type III: fleshy) as shown in Figure 1.

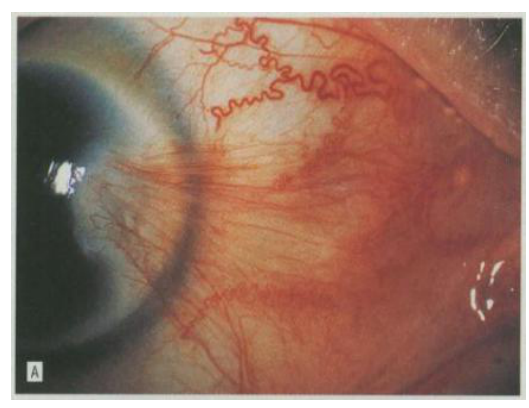

(a)

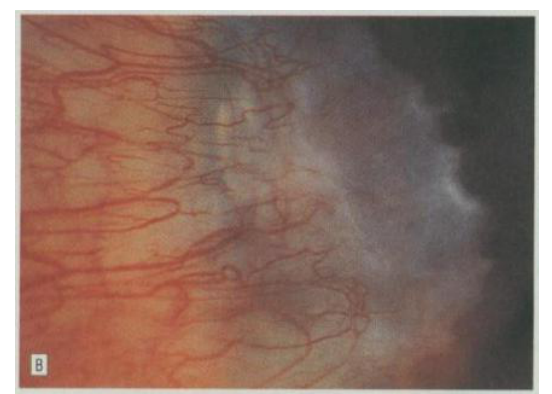

(b)

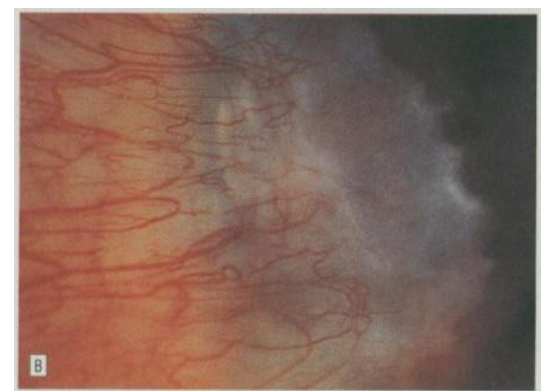

(c)

FIGURE 1. Tan's Classification of Pterygia (a) Type 1, (b) Type 2, (c) Type 3 


\section{RESULTS AND DISCUSSION}

This study recruited 93 participants, and 50.5\% (n = $47)$ were men. The mean ( \pm standard deviation) age and computed redness (PRGS) were $57.42 \pm 11.55$ years and $1.81 \pm 0.58$, respectively. Descriptive analysis (n =93) showed that redness measured using PRGS was comparable to expert grading, with values of $1.81 \pm 0.58$ and $1.73 \pm 0.61$, respectively $(\mathrm{P}=0.396)$.

In all 93 cases, primary pterygia were further classified into three groups based on pterygium types, and comparative analysis using a paired t-test was performed to evaluate the difference in redness measured using PRGS and expert grading in each pterygium group. The results of the paired t-test showed no significant difference in pterygium redness measured using PRGS and expert grading in all pterygium groups (all $\mathrm{P}>0.05$; Table 1). ICC analysis was employed to evaluate and compare the reliability of redness measured using PRGS to that of expert grading in each pterygium group. The analysis showed robust associations between redness measured using both approaches in all pterygium groups $(\mathrm{r}>0.9)$.

Table 2 describes the reliability estimates based on PRGS and expert grading in all pterygium groups. The ICC findings showed that PRGS could distinguish pterygium types based on their redness appearance (ICC, all $r>0.90)$.

This study aimed to verify the validity and reproducibility of PRGS in describing pterygia based on redness. PRGS was developed to address an essential issue regarding the lack of standardisation in assessing pterygia. Currently, several methods are available for describing pterygia, including methods based on pterygium size, length, and morphology. However, these methods are based on subjective grading. Hence, individual variations could lead to a bias.

PRGS aimed to standardise the assessment of pterygia based on redness which was objectively measured. The study results showed that redness measured using PRGS was comparable to expert grading $(\mathrm{n}=93, \mathrm{P}>0.05)$. When primary pterygia were categorized into different groups, PRGS could cluster all primary pterygia $(n=93)$ into three groups based on redness which was graded on a continuous scale of $0-0.99$ (minimum redness), 1.00-1.99 (moderate redness), and 2.00-3.00 (maximum redness), and these findings were in agreement with those of a previous study (Mohd Radzi et al. 2017). The current study highlights that pterygium redness measured using PRGS was in agreement with the pterygium types shown in Table 2 . This indirectly showed that PRGS can be used to differentiate pterygium types. Thus, by adopting Tan's classification of pterygia, the combination of a translucent appearance of pterygium and its redness could indicate a higher probability of pterygium progression.
Redness has been used as a clinical predictor in automated assessments of anterior eye structures, such as the bulbar conjunctiva, eyelid, and cornea (Downie et al. 2016; Efron 1998; Fieguth \& Simpson 2002). PRGS adopts a similar concept of integrating redness into the assessments of anterior eye structures; however, PRGS was developed specifically for evaluating pterygia and for clinically predicting the changes in oculo-visual function (Mohd Radzi et al. 2020). PRGS was developed (Mohd Radzi et al. 2017) using a combination of selective hybrid features, including entropy, vesselness, texture analysis, and average pixel values on images using specific colour spaces. This is important as the pterygium surface on the conjunctival area is not smooth, and is in fact quite rough. Thus, if a measurement was made considering that the pterygium surface is smooth, it would yield inaccurate findings.

Previously, many methods have been used to provide an objective grading, including edge detection (Amparo et al. 2017; Chun et al. 2014; Peterson \& Wolffsohn 2009; Sánchez Brea et al. 2016), colour extraction (Chun et al. 2014; Efron 1998; Papas 2000; Sumi et al. 2013), smoothing (Peterson \& Wolffsohn 2009; Schulze et al. 2008, 2007; Zhao et al. 2014), thresholding (Amparo et al. 2017; Fieguth \& Simpson 2002; Jiang et al. 2014; Papas 2000; Schulze et al. 2009; Wolffsohn \& Purslow 2003), densitometry (Chun et al. 2014), and morphometry (Romano et al. 2017), with the aim to mimic normal human colour perception. An objective assessment of pterygia may improve the reliability and consistency of measurements (Fieguth \& Simpson 2002; Papas 2000; Peterson \& Wolffsohn 2009; Schulze et al. 2009, 2007; Wolffsohn 2004), thereby indirectly reducing subjective bias and individual variability (Peterson \& Wolffsohn 2009; Schulze et al. 2011; Zhao et al. 2014).

In this study, PRGS could detect a significant difference in pterygium types relative to their translucency. The study results also showed an increased amount of redness with a higher grade of pterygium $(\mathrm{P}<0.05)$. Pterygium redness might signify an active lesion which could grow into a larger or thicker pterygium lesion. Previous studies reported that mast cell degranulation was twice as high in pterygium tissue than in normal tissue (Džunic et al. 2010; Qin et al. 2016; Ribatti et al. 2009, 2007; Sha et al. 2014; Touhami et al. 2005), thereby indicating that chronic inflammation is a possible cause of pterygium. Hence, this study demonstrates that PRGS could be used to further classify pterygium groups according to their redness measurements. PRGS can be further utilised and refined to meet its purpose which is to predict the effect of pterygium morphology on the changes in anterior corneal curvature. 
TABLE 1. Comparison of redness measurements between PRGS and expert grading based on different types of pterygia

\begin{tabular}{lcccc}
\hline Variable & \multicolumn{3}{c}{ Pterygium type } & P-value* \\
Redness & Type $\mathrm{I}^{\mathrm{a}}(\mathrm{n}=30)$ & ${\text { Type } \mathrm{II}^{\mathrm{b}}(\mathrm{n}=32)}^{\text {Type } \mathrm{III}^{\mathrm{c}}(\mathrm{n}=31)}$ \\
\hline PRGS & $1.43 \pm 0.32$ & $1.67 \pm 0.55$ & $2.31 \pm 0.46$ & $0.594^{\mathrm{a}}$ \\
Expert & $1.38 \pm 0.34$ & $1.78 \pm 0.62$ & $2.02 \pm 0.66$ & $0.446^{\mathrm{b}}$ \\
& & & & $0.185^{\mathrm{c}}$ \\
\hline
\end{tabular}

PRGS: Pterygium Redness Grading Software

": Based on the independent t-test, with significance level set at 0.05 (two-tailed)

a: P-value between PRGS and Expert for Type I

b: P-value between PRGS and Expert for Type II

c: P-value between PRGS and Expert for Type III

TABLE 2. Reliability estimates for redness measurements in different types of pterygia based on PRGS and expert grading

\begin{tabular}{llc}
\hline Inter-grader (PRGS and Expert) & ICC $^{*}$ & $95 \% \mathrm{CI}^{\#}$ \\
\hline Type I $(\mathrm{n}=30)$ & 0.910 & $0.86,0.93$ \\
Type II $(\mathrm{n}=32)$ & 0.922 & $0.90,0.94$ \\
Type III $(\mathrm{n}=31)$ & 0.954 & $0.92,0.96$ \\
\hline
\end{tabular}

PRGS: Pterygium Redness Grading Software

\#: Confidence interval

\section{CONCLUSION}

This study describes the use of PRGS in describing pterygium redness in different pterygium groups. A better understanding of pterygium morphology is important in predicting pterygium progression and in clinical decision-making.

\section{ACKNOWLEDGEMENTS}

This research project was funded by the Ministry of Education (MOE) under the Prototype Research Grant Scheme (PRGS) (Ref: PRGS/1/2018/SKK06/ UIAM/02/1), and this study is financially supported by the International Islamic University Malaysia (IIUM) under the Publication-Research Initiative Grant Scheme (P-RIGS) P-RIGS18-035-0035.

\section{REFERENCES}

Altan-Yaycioglu, R., Kucukerdonmez, C., Karalezli, A., Corak, F. \& Akova, Y.A. 2013. Astigmatic changes following pterygium removal: Comparison of 5 different methods. Indian J. Ophthalmol. 61: 104-108.

Amparo, F., Yin, J., Di Zazzo, A., Abud, T., Jurkunas, U.V., Hamrah, P. \& Dana, R. 2017. Evaluating changes in ocular redness using a novel automated method. Transl. Vis. Sci. Technol. 6(4): 13. doi: 10.1167/tvst.6.4.13.

Azemin, M.Z.C., Hilmi, M.R. \& Kamal, M.K. 2014. Supervised pterygium fibrovascular redness grading using generalized regression neural network. In New Trends in Software Methodologies, Tools and Techniques, edited by Fujita, H. Amsterdam: IOS Press.

Bradley, J.C., Yang, W., Bradley, R.H., Reid, T.W. \& Schwab, I.R. 2010. The science of pterygia. Br. J. Ophthalmol. 94(7): 815-820.

Che Azemin, M.Z., Mohd Tamrin, M.I., Hilmi, M.R. \& Mohd Kamal, K. 2015. GLCM texture analysis on different color space for pterygium grading. ARPN J. Eng. Appl. Sci. 10: 6410-6413.

Che Azemin, M.Z., Hilmi, M.R., Mohd Tamrin, M.I. \& Mohd Kamal, K. 2014. Fibrovascular redness grading using Gaussian process regression with radial basis function kernel. In 2014 IEEE Conference Biomedical Engineering and Sciences (IECBES). pp. 113-116. 
Chui, J., Coroneo, M.T., Tat, L.T., Crouch, R., Wakefield, D. \& DiGirolamo, N. 2011. Ophthalmic pterygium: A stem cell disorder with premalignant features. Am. J. Pathology 178(2): 817-827.

Chun, Y.S., Yoon, W.B., Kim, K.G. \& Park, I.K. 2014. Objective assessment of corneal staining using digital image analysis. Invest. Ophthalmol. Vis. Sci. 55(12): 7896-7903.

Downie, L.E., Keller, P.R. \& Vingrys, A.J. 2016. Assessing ocular bulbar redness: A comparison of methods. Ophthalmic. Physiol. Opt. 36(2): 132-139.

Džunic, B., Jovanović, P., Veselinović, D., Petrović, A., Stefanović, I. \& Kovaćević, I. 2010. Analysis of pathohistological characteristics of pterygium. Bosn. J. of Basic Med. Sci. 10(4): 307-313.

Efron, N. 1998. Grading scales for contact lens complications. Ophthalmic. Physiol. Opt. 18: 182-186.

Farhood, Q.K. \& Kareem, A.A. 2012. Pterygium and induced astigmatism. Kufa Med. Journal 15(11): 341-345.

Fieguth, P. \& Simpson, T. 2002. Automated measurement of bulbar redness. Invest. Ophthalmol. Vis. Sci. 43: 340-347.

Gumus, K., Erkilic, K., Topaktas, D. \& Colin, J. 2011. Effect of pterygia on refractive indices, corneal topography, and ocular aberrations. Cornea 30(1): 24-29.

Hilmi, M.R., Khairidzan, M.K., Azemin, M.Z.C., Azami, M.H. \& Ariffin, A.E. 2019. Corneopterygium total area measurements utilizing image analysis method. J. Optom. 12(4): 272-277.

Hilmi, M.R., Khairidzan, M.K., Azemin, M.Z.C., Azami, M.H. \& Ariffin, A.E. 2018. Measurement of contrast sensitivity using the M\&S Smart System II compared with the standard Pelli-Robson Chart in patients with primary pterygium. Makara. J. Health Res. 22(3): 167-171.

Jiang, H., Zhong, J., DeBuc, D.C., Tao, A., Xu, Z., Lam, B.L, Liua, C. \& Wang, J. 2014. Functional slit lampbiomicroscopy for imaging bulbar conjunctival microvasculature in contact lens wearers. Microvasc. Res. 92: 62-71.

Kheirkhah, A., Safi, H., Nazari, R., Kaghazkanani, R., Hashemi, H. \& Behrouz, M.J. 2012a. Effects of pterygium surgery on front and back corneal astigmatism. Int. Ophthalmol. 32: 251-257.

Kheirkhah, A., Safi, H., Molaei, S., Nazari, R., Behrouz, M.J. \& Raju, V.K. 2012b. Effects of pterygium surgery on front and back corneal surfaces and anterior segment parameters. Can. J. Ophthalmol. 47(5): 423-428.

Manzar, N. \& Mahar, P.S. 2013. Pterygium recurrence related to its size and corneal involvement. J. Coll. Physicians Surg. Pak. 23(2): 120-123.

Modenese, A. \& Gobba, F. 2017. Occupational exposure to solar radiation at different latitudes and pterygium: A systematic review of the last 10 years of scientific literature. Int. J. Environ. Res. Public Health. 15(1): E37. doi: 10.3390/ ijerph15010037.

Mohd Radzi, H., Khairidzan, M.K., Ariffin, A.E., Norazmar, N.A., Maruziki, N.N., Musa, N.H., Nasir, M.S., Azemin, M.Z.C., Azami, M.H. \& Abdul Rahim, M.A.S. 2020. Effects of different types of primary pterygium on changes in oculovisual function. Sains Malaysiana 49(2): 383-388.

Mohd Radzi, H., Mohd Zulfaezal, C.A., Khairidzan, M.K., Mohd Izzuddin, M.T., Norfazrina, A.G. \& Tengku Mohd, T.S. 2017. Prediction of changes in visual acuity and contrast sensitivity function by tissue redness after pterygium surgery. Curr. Eye Res. 42: 852-856.
Mohammad-Salih, P.A.K. \& Sharif, A.F.M.D. 2008. Analysis of pterygium size and induced corneal astigmatism. Cornea 27: 434-438.

Oellers, P., Karp, C.L., Sheth, A., Kao, A.A., Abdelaziz, A., Matthews, J.L., Dubovy, S.R. \& Galor, A. 2013. Prevalence, treatment, and outcomes of coexistent ocular surface squamous neoplasia and pterygium. Ophthalmology 120: 445-450.

Papas, E.B. 2000. Key factors in the subjective and objective assessment of conjunctival erythema. Invest. Ophthal. Vis. Sci. 41: 687-691.

Park, Y.M., Kim, C.D. \& Lee, J.S. 2015. Effect of bevacizumab on human tenon's fibroblasts cultured from primary and recurrent pterygium. Korean J. Physiol. Pharmacol. 19(4): 357-363.

Peterson, R.C. \& Wolffsohn, J.S. 2009. Objective grading of the anterior eye. Optom. Vis. Sci. 86: 273-278.

Qin, Z., Fu, Q., Zhang, L., Yin, H., Jin, X., Tang, Q., Danni, L. \& Yao, K. 2016. Proliferative effects of histamine on primary human pterygium fibroblasts. Mediators Inflamm. 2016: 9862496.

Ribatti, D., Nico, B., Perra, M.T., Maxia, C., Piras, F., Murtas, D., Crivellato, E. \& Sirigu, P. 2009. Correlation between NGF/ TrkA and microvascular density in human pterygium. Int. $J$. Exp. Pathology. 90(6): 615-620.

Ribatti, D., Nico, B., Maxia, C., Longo, V., Murtas, D., Mangieri, D., Perra, M.T., De Giorgis, M., Piras, F., Crivellato, E. \& Sirigub, P. 2007. Neovascularization and mast cells with tryptase activity increase simultaneously in human pterygium. J. Cell. Molec. Med. 11(3): 585-589.

Romano, V., Steger, B., Brunner, M., Kaye, A., Zheng, Y. \& Willoughby, C.E. 2017. Detecting change in conjunctival hyperemia using a pixel densitometry index. Ocul. Immunol. Inflamm. pp: 1-6.

Sánchez, B.M.L., Rodríguez, B.N., González, A.M., Evans, K. \& Pena-Verdeal, H. 2016. Defining the optimal region of interest for hyperemia grading in the bulbar conjunctiva. Comput. Math. Methods Med. 2016: 3695014. doi: 10.1155/2016/3695014.

Schulze, M.M., Hutchings, N. \& Simpson, T.L. 2011. Grading bulbar redness using cross calibrated clinical grading scales. Invest. Ophthalmol. Vis. Sci. 52: 5812-5817.

Schulze, M.M., Hutchings, N. \& Simpson, T.L. 2009. The perceived bulbar redness of clinical grading scales. Optom. Vis. Sci. 84: 1250-1258.

Schulze, M.M., Hutchings, N. \& Simpson, T.L. 2008. The use of fractal analysis and photometry to estimate the accuracy of bulbar redness grading scales. Optom. Vis. Sci. 49: 1398-1406.

Schulze, M.M., Jones, D.A. \& Simpson, T.L. 2007. The development of validated bulbar redness grading scales. Optom. Vis. Sci. 84: 976-983.

Sha, X., Wen, Y., Liu, Z., Song, L., Peng, J. \& Xie, L. 2014. Inhibition of $\alpha$-smooth muscle actin expression and migration of pterygium fibroblasts by coculture with amniotic mesenchymal stem cells. Curr. Eye Res. 39(11): 1081-1089.

Sumi, T., Yoneda, T., Fukuda, K., Hoshikawa, Y., Kobayashi, M., Yanagi, M. Kiuchi, Y., Yasumitsu-Lovell, K. \& Fukushima, A. 2013. Development of automated conjunctival hyperemia analysis software. Cornea 32: 52-59.

Tan, D.T., Chee, S.P., Dear, K.B. \& Lim, A.S. 1997. Effect of pterygium morphology on pterygium recurrence in a 
controlled trial comparing conjunctival autografting with bare sclera excision. Arch. Ophthalmol. 115: 1235-1240.

Touhami, A., Di Pascuale, M.A., Kawatika, T., Del Valle, M., Rosa Jr., R.H., Duvony, S. \& Tseng, S.C.G. 2005. Characterisation of myofibroblasts in fibrovascular tissues of primary and recurrent pterygia. Br. J. Ophthalmol. 89(3): 269-274.

Urbaniak, G.C. \& Plous, S. 2013. Research Randomizer (Version 4.0)[computer software]. http://www.randomizer. org/. Accessed on June 192013.

Vives, P.P., Castanheira, A.M.C.M., Mora, G.J., Margarit, S.L., Encina, D.M. \& Garcia, I.S. 2013. Topographic corneal changes in astigmatism due to pterygium's limbalconjunctival autograft surgery. J. Emmetropia. 4: 13-18.

Wolffsohn, J.S. \& Purslow, C. 2003. Clinical monitoring of ocular physiology using digitalimage analysis. Cont. Lens Anterior Eye 26(1): 27-35.

Wolffsohn, J.S. 2004. Incremental nature of anterior eye grading scales determined by objective image analysis. $\mathrm{Br}$. J. Ophthalmol. 88: 1434-1438.

Zhao, W.J., Duan, F., Li, Z.T., Yang, H.J., Huang, Q. \& Wu, K.L. 2014. Evaluation of regional bulbar redness using an image-based objective method. Int. J. Ophthalmol. 7(1): 71-76.

Mohd Radzi Hilmi, Mohd Zulfaezal Che Azemin \& Muhammad Afzam Shah Abdul Rahim

Department of Optometry and Vision Science

Kulliyyah of Allied Health Sciences

International Islamic University Malaysia (IIUM)

25200 Kuantan, Pahang Darul Makmur

Malaysia
Khairidzan Mohd Kamal*

Department of Ophthalmology

Kulliyyah of Medicine

International Islamic University Malaysia (IIUM)

25200 Kuantan, Pahang Darul Makmur

Malaysia

Azrin Esmady Ariffin

Faculty of Optometry and Vision Science

SEGi University

47810 Petaling Jaya, Selangor Darul Ehsan

Malaysia

Mohd Izzuddin Mohd Tamrin

Department of Information Systems

Kulliyyah of Information and Communication Technology International Islamic University Malaysia (IIUM)

53100 Gombak, Selangor Darul Ehsan

Malaysia

*Corresponding author; email: khairidzan@gmail.com

Received: 27 March 2019

Accepted: 15 January 2020 